\title{
GENUS EREMOPSOCUS MCLACHLAN: DISTINCTION FROM CERASTIPSOCUS KOLBE AND REVIEW OF SPECIES (PSOCOPTERA: PSOCIDAE)*
}

\author{
By Edward L. MOCKFord \\ Department of Biological Sciences \\ Illinois State University \\ Normal, Illinois 6r 761
}

During investigation on the systematics of Cerastipsocus and its close relatives, I have experienced difficulty in assigning species between the two genera Eremopsocus and Cerastipsocus. In this paper, I attempt an unequivocal definition of these genera. I also include diagnoses of the species placed by the new definition in Eremopsocus, and a reconsideration of geographic variation in the type species, $E$. infumatus McLachlan. The subgenera of Eremopsocus are also reevaluated. One new species is described.

Measurements ('Table II) were made on whole specimens either pinned or temporarily mounted in glycerine. They are in $\mathrm{mm}$ and have an error of \pm I.04 microns. Abbreviations used with the measurements are explained as follows: $f_{1}, f_{2}=$ lengths of first and second flagcllomeres; $\mathrm{F}_{\mathrm{W}}=$ forewing length; $\mathrm{F}=$ length of posterior femur; $T=$ length of posterior tibia; $t_{1}, t_{2}=$ length of first and second posterior tarsomeres; $t_{1} \mathrm{ct}=$ number of ctenidia on posterior first tarsomeres; IO/D = least distance between compound eyes in dorsal view divided by greatest antero-posterior diameter of eye in dorsal view; $\mathrm{PO}=$ greatest transverse diameter of compound eye in dorsal view divided by greatest antero-posterior diameter of the eye in same view.

Characters of Eremopsocus and distinction from Cerastipsocus. Eremopsocus McLachlan ( I866) was erected for a single large Brazilian species, E. infumatus, with fuscous wing membranes. This species was reported to have incrassate flagellomeres in the male only, those of the female being slender. This antennal character, alone, was held to separate the genus from Psocus, which was then used in a very broad sense.

Pearman (1933) correctly aligned Eremopsocus with its close relatives by placing it in subfamily Cerastipsocinae of Family Psocidae. Pearman's material, from Venezuela, showed incrassate flagellomeres in both sexes, and on that account, he designated a distinct subspecies, E. infumatus venezuelensis.

*Manuscript received by the editor August 15, 1975. 
I have examined 15 adult specimens of this species from two localities in central Brazil, and I find that all individuals of both sexes have antennae incrassate. I believe that McLachlan's observation was incorrect and that the error arose from his having had more than one large, fuscous-winged Cerastipsocine species in his material. There are several such species in Brazil. Those with slender flagellomeres in both sexes are currently assigned to Cerastipsocus. The argument for McLachlan's having had a mixture of species is strengthened by another of his observations: that males have wings shining, while females have them dull. Pinned specimens in the series of $E$. infumatus which I studied have the wings shining in both sexes whilc pinned specimens of Cerastipsocus fuscipennis (Burmeister) received in the same shipment from a nearby locality in Brazil have the wings dull. I conclude that the flagellomeres of both sexes of E. infumatus are incrassate and that Pearman's Venezuelan subspecies has no validity.

Pearman (1933) described the genitalia of both sexes of $E$. infumatus. The hypandrium is symmetrical and bears an apically rounded lobe in the middle of the disc; distally, it bears a pair of blunt, posteriorly-directed prongs. This hypandrium differs from that of the type of Cerastipsocus (C. fuscipennis [Burmeister], designated by Roesler [1944], not $C$. venosus [Burmeister], erroneously designated by Smithers [1967]).

In $C$. fuscipennis, there is no trace of a rounded lobe in the middle of the disc and distal prongs are absent. This type of hypandrium has been illustrated for C. cubanus Enderlein (Mockford, 1974: I64, Fig. II 8 ) and C. venosus Burmeister (Chapman, 1930, pl. XIII, Fig. 9). C. beaveri New (1972: 207, Fig. 32) is much the same but its hypandrium has a pair of short, laterally directed distal prongs.

The distinctive hypandria of the types of Eremopsocus and Cerastipsocus provide useful character complexes for distinguishing between these two genera. Unfortunately, these complexes do not correlate with the distribution of incrassate and slender flagellomeres in the species as currently assigned in these two genera. Thus $E$. reductus (Banks) has the flagellomeres developed as in E. infumatus but the hypandrium as in $C$. venosus, completely lacking a lobe in the middle of the disc and without distal prongs (personal observation). C. crassicornis (Kolbe) in which the male has only the first flagellomere incrassate and the flagellomeres of the female are slender has the hypandrium developed as in E. infumatus (personal observation). 

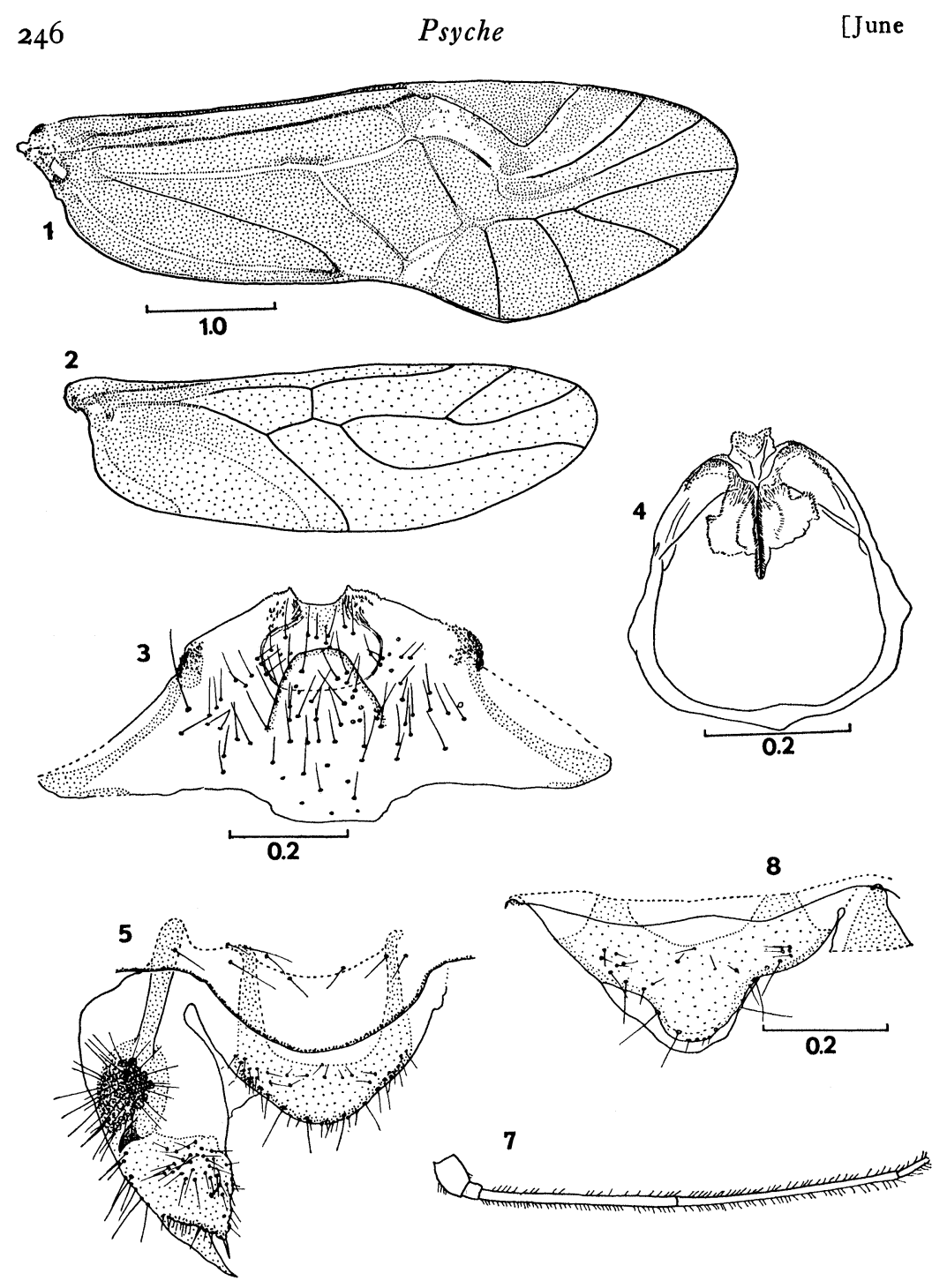

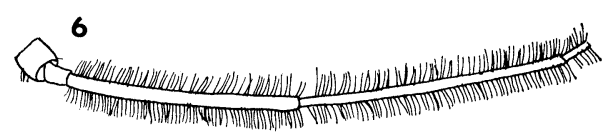


It is my opinion that the hypandrium in these insects presents more information than the relative widths of flagellomeres and that the two genera can best be recognized on the basis of type of hypandrium. This opinion is strengthened by the fact that no intermediate type of hypandrium has been found, whereas flagellomeres of different species show varying degrees of incrassation.

In order to test this opinion further I have searched for additional characters showing essentially two states in the assemblage of species under consideration and noted how their states are distributed. The following characters were found:

(I) shape of posterior clunial margin of male in region of base of epiproct: slightly protruding and bilobed (Fig. 8) or decidedly protruding and not at all bilobed (Fig. 5);

(2) presence (Fig. 5) or absence of a protuberance immediately distad of sense cushion on paraproct in male;

(3) relative length of stem of dark T-shaped mark of female subgenital plate (stem of vase-shaped figure extending into distal process of plate): either more than twice as long as broad or scarcely longer than broad to much shorter than broad.

The following species were examined (assigned to genera according to current usage): Cerastipsocus bogotanus (Kolbe), C. crassicornis (Kolbe), C. cubanus Enderlein, C. fuscipennis (Burmeister), C. vochraceocristatus Enderlein, C. sivorii Ribaga, C. trifasciatus (Provancher), C. vienosus (Burmeister), two undetermined species of Cerastipsocus, Eremopsocus infumatus McLachlan, and E. reductus (Banks).

The data are summarized in Table I. From this table, the following correlations are seen:

I. Incrassate flagellomeres correlate with hypandrial type of $E$. infumatus. The notable exception is $E$. reductus, while $C$. cubanus shows slight incrassation.

\section{Explanation of Figures 1-8}

Fig. 1. Eremopsocus crassicornis (Kolbe) $\hat{o}$, forewing, scales in $\mathrm{mm}$. Fig. 2. E. crassicornis (Kolbe) $\hat{o}$, hindwing. Fig. 3. E. crassicornis (Kolbe) $\hat{o}$, hypandrium. Fig. 4. E. crassicornis (Kolbe) $\hat{o}$, phallosome. Fig. 5. E. crassicornis (Kolbe) $\hat{o}$, epiproct, left paraproct, and adjacent clunial margin, scale of Fig. 3. Fig. 6. E. crassicornis (Kolbe) $\hat{o}$, antenna (scape to base of $f_{3}$ ), scale of Fig. 1. Fig. 7. E. crassicornis (Kolbe) $ᄋ$, antenna (scape to base of $f_{3}$ ), scale of Fig. 1. Fig. 8. Cerastipsocus venosus (Burmeister) $\hat{\delta}$, epiproct, base of right paraproct, and adjacent clunial margin. 


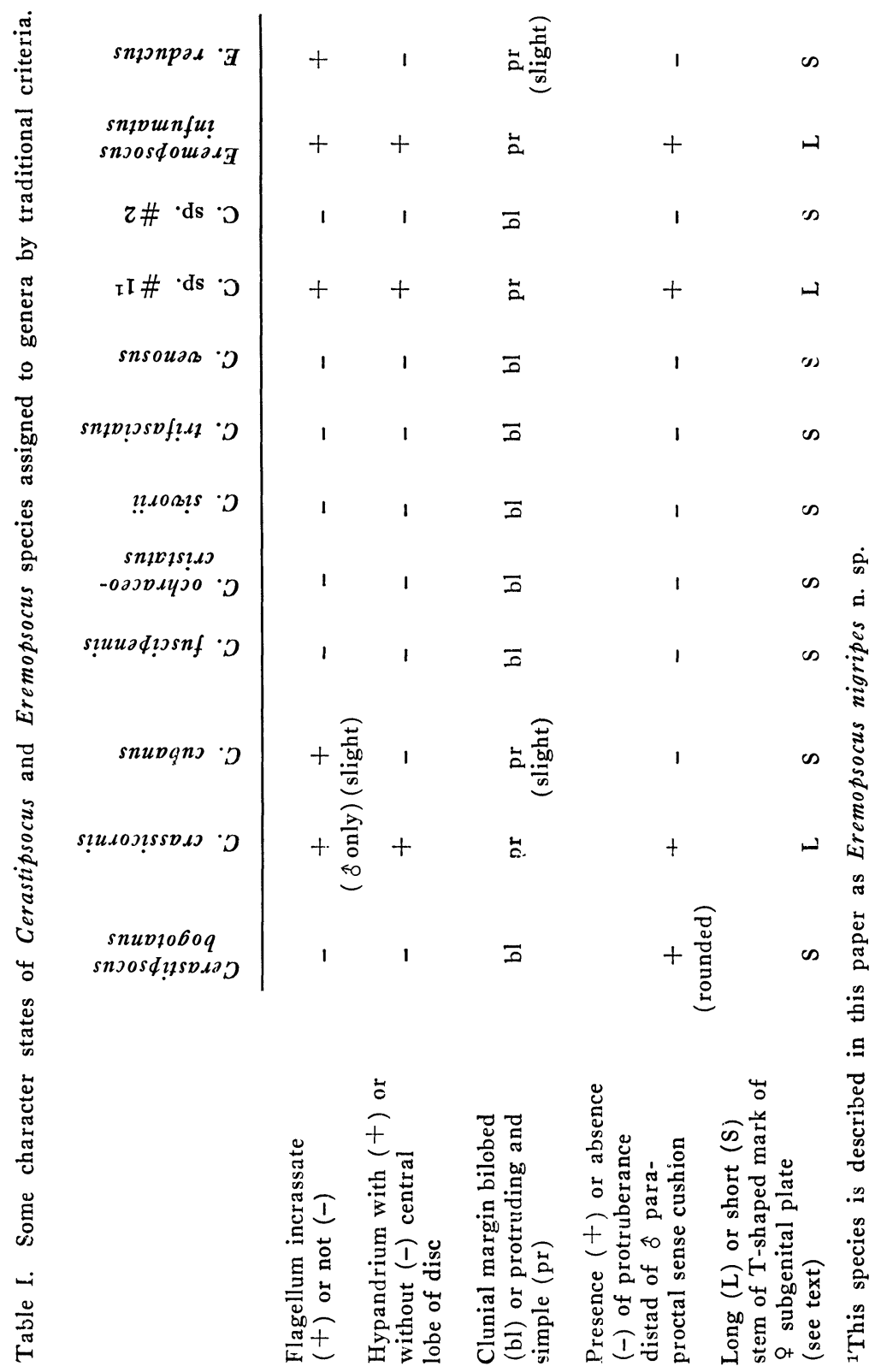


2. The protruding male clunial margin tends to correlate with the $E$. infumatus hypandrial type, while the bilobed male clunial margin tends to correlate with the $C$. venosus hypandrial type. This correlation is better than indicated on the table. In E. infumatus, C. crassicornis, and $C$. sp. no. I, the protrusion is a thickened lip, while in C. cubanus and E. reductus it is only a thin rim, as in those species with the bilobed margin.

3. The protuberance distad of the male paraproctal sense cushion tends to correlate with the $E$. infumatus hypandrial type and absence of the protuberance with the $C$. venosus hypandrial type. Again, the correlation seems better than the table suggests, as the protuberance in E. infumatus, $C$. crassicornis, and $C$. sp. no. I is small and decidedly pointed, while that in C. bogotanus is low, larger, and rounded.

4. The long stem of the T-shaped mark of the female subgenital plate shows complete correlation with the $E$. infumatus hypandrial type and the shorter stem with the $C$. venosus hypandrial type.

From the above correlations, I conclude that the genera Eremopsocus and Cerastipsocus may be differentially defined as follows:

Eremopsocus. - Antennae incrassate at least in male; hypandrium with central lobe of disc; male clunial margin protruding above epiproctal base as a rounded, thickened lip; a pointed protuberance distad of male paraproctal sense cushion; stem of $\mathrm{T}$-shaped mark of female subgenital plate more than twice as long as broad.

Cerastipsocus. - Antennae incrassate or not; hypandrium lacking central lobe of disc; male clunial margin bilobed before base of epiproct or slightly protruding above epiproctal base but never developed as a decidedly protruding, thickened lip; generally lacking a protuberance distad of male paraproctal sense cushion, or with a low, rounded protuberance; stem of T-shaped mark of female subgenital plate little longer than broad to much shorter than broad.

Assignment of species to Cerastipsocus and Eremopsocus. - I can affirm, either through examination of specimens or by existing published descriptions, the generic assignment of the following species according to the above definitions:

Cerastipsocus. - C. fuscipennis (Burmeister) (type species), $C$. beaveri New, C. bogotanus (Kolbe), C. cubanus Enderlein, C. ochraceocristatus (Enderlein), C. reductus (Banks), new combination, C. sivorii (Ribaga), new combination, C. trifasciatus (Provancher), C. venosus (Burmeister). 

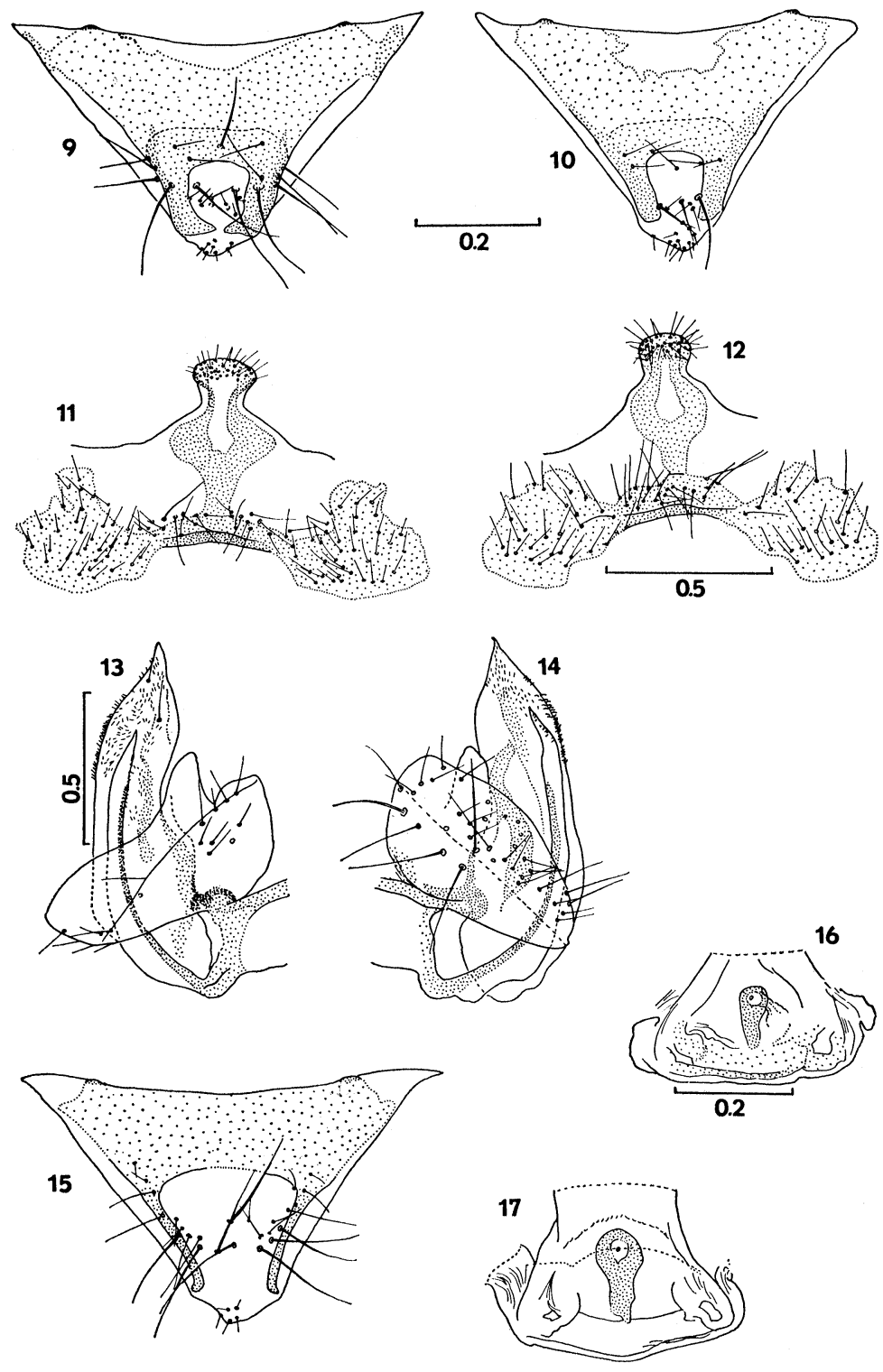
Eremopsocus. - E. infumatus McLachlan (type species), E. crassicornis (Kolbe) new combination, E. nigripes n. sp. (heretofore referred to in this paper as Cerastipsocus sp. no. I).

Several species traditionally assigned to Cerastipsocus are unassignable by the above definition, and I hope to review that genus and assign these species in the near future.

Subgenera of Eremopsocus. - Roesler (1944) assigned Syngonosoma Kolbe, Dinopsocus Banks, and Podopterocus Banks as subgenera of Eremopsocus. These assignments were presumably made on the basis of incrassate flagellomeres alone. As I have shown that this character is not a reliable guide to relationships, it seems advisable to retain the old-world genera Dinopsocus and Podopterocus at least until their external genitalia are known. The type of Syngonosoma being South American, it seems likely that this genus may be a synonym (not a subgenus) of Eremopsocus as was suggested by Enderlein (I9II) and Pearman (I933), but is will be necessary to examine material of the type species in order to confirm this suggestion. Of the species listed in Eremopsocus by Smithers (1967), only the type species can be retained with certainty.

Systematics of Eremopsocus species. - In this section the species now assigned to Eremopsocus are diagnosed, the description of $E$. infumatus is augmented, a detailed description of $E$. crassicornis is presented and E. nigripes n. sp. is described. A key to the species is included.

\section{Eremopsocus infumatus McLachlan}

E. infumatus McLachlan, 1866: 348.

E. infumatus venezuelensis Pearman 1933: 159.

Diagnosis. - First four flagellomeres incrassate in both sexes, the basal two decidedly so, the next two somewhat less. Female subgenital plate with a single row of long setae along cross-piece of T-shaped mark (the row double to the sides and single in middle on specimen examined).

\section{Explanation of Figures 9-17}

Fig. 9. Eremopsocus crassicornis (Kolbe) $ᄋ$, epiproct. Fig. 10. E. nigripes $\mathrm{n}$. sp. + , epiproct. Fig. 11. E. crassicornis (Kolbe) + , subgenital plate, scale of Fig. 12. Fig. 12. E. nigripes n. sp. $\$$, subgenital plate. Fig. 13. E. crassicornis (Kolbe) + , gonapophyses. Fig. 14. E. nigripes n. sp. + , gonapophyses, scale of Fig. 9. Fig. 15. E. infumatus McLachlan , epiproct, scale of Fig. 9. Fig. 16. E. crassicornis (Kolbe) $\$$, spermapore sclerite. Fig. 17. E. nigripes n. sp. + , spermapore sclerite, scale of Fig. 16. 
Pearman's description (1933) is augmented as follows: Measurements (Table II). Lateral prongs of hypandrium joined along their length to sides of hypandrium by semimembranous cuticle. Female epiproct (Fig. I5) with postero-lateral sclerotized strips turning slightly outward at their distal ends.

Material examined. - Brazil: Goias: Jatai, October, 1972 i ㅇ F. M. Oliveira; $20 \mathrm{Km}$. north of Sao Joao da Alianca, April I4, 1956, I $0^{\star}, 13$ i, F. S. Truxal.

Eremopsocus crassicornis (Kolbe), new combination

Cerastis crassicornis Kolbe, 1883: 70.

Cerastipsocus crassicornis (Kolbe), Smithers, 1967: 96.

Diagnosis. - See diagnosis of E. nigripes n. sp.

Male. - Measurements (Table II).

Morphology. - Antenna with basal flagellomere (Fig. 6) decidedly incrassate, second less so, third slightly incrassate basally; all flagellomeres densely beset with upright hairs. Compound eyes small (see Table II). Hypandrium (Fig. 3) with pair of short distal prongs; these and distal ends of lateral thickenings beset with minute denticles. Discal lobe and regions to its sides and base bearing setae. Phallosome (Fig. 4) a closed ring with truncate distal process, the process and weakly-sclerotized region to its sides bearing minute denticles. Paraproct (Fig. 5) with a long distal spur and a short spur distad of sense cushion. Epiproct and posterior clunial margin as in Fig. 5 .

Color (in alcohol). - Compound eyes and inner rims of ocelli black. Head deep orange-brown with faint clypeal striations. Maxillary palpi dark brown. Antennal scape and pedicel dark chestnut brown; flagellum black. Mesonotal lobes deep to medium chestnut brown, their borders and thoracic pleura orange-brown. Forewing membrane (Fig. I) uniformly fumose-brown except colorless in base of areola postica and nearly so in basal region of cell $\mathrm{R}_{\mathrm{I}}$ from behind stigmasac nearly to apex of pterostigma. Pterostigma brown

Explanation OF Figures $18-24$

Fig. 18. Eremopsocus nigripes n. sp. $\hat{o}$, forewing. Fig. 19. E. nigripes n. sp. $\hat{\jmath}$, hindwing. Fig. 20 . E. nigripes n. sp. $\hat{o}$, hypandrium. Fig. 21. E. nigripes n. sp. $\hat{\delta}$, phallosome. Fig. 22 . E. nigripes n. sp. $\hat{o}$, epiproct, left paraproct, and adjacent clunial margin, scale of Fig. 20. Fig. 23. E. nigripes n. sp. $\hat{o}$, antenna (scape through base of $f_{3}$ ), scale of Fig. 18.

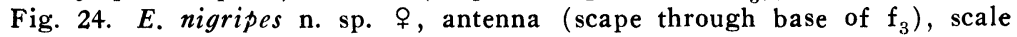
of Fig. 18. 


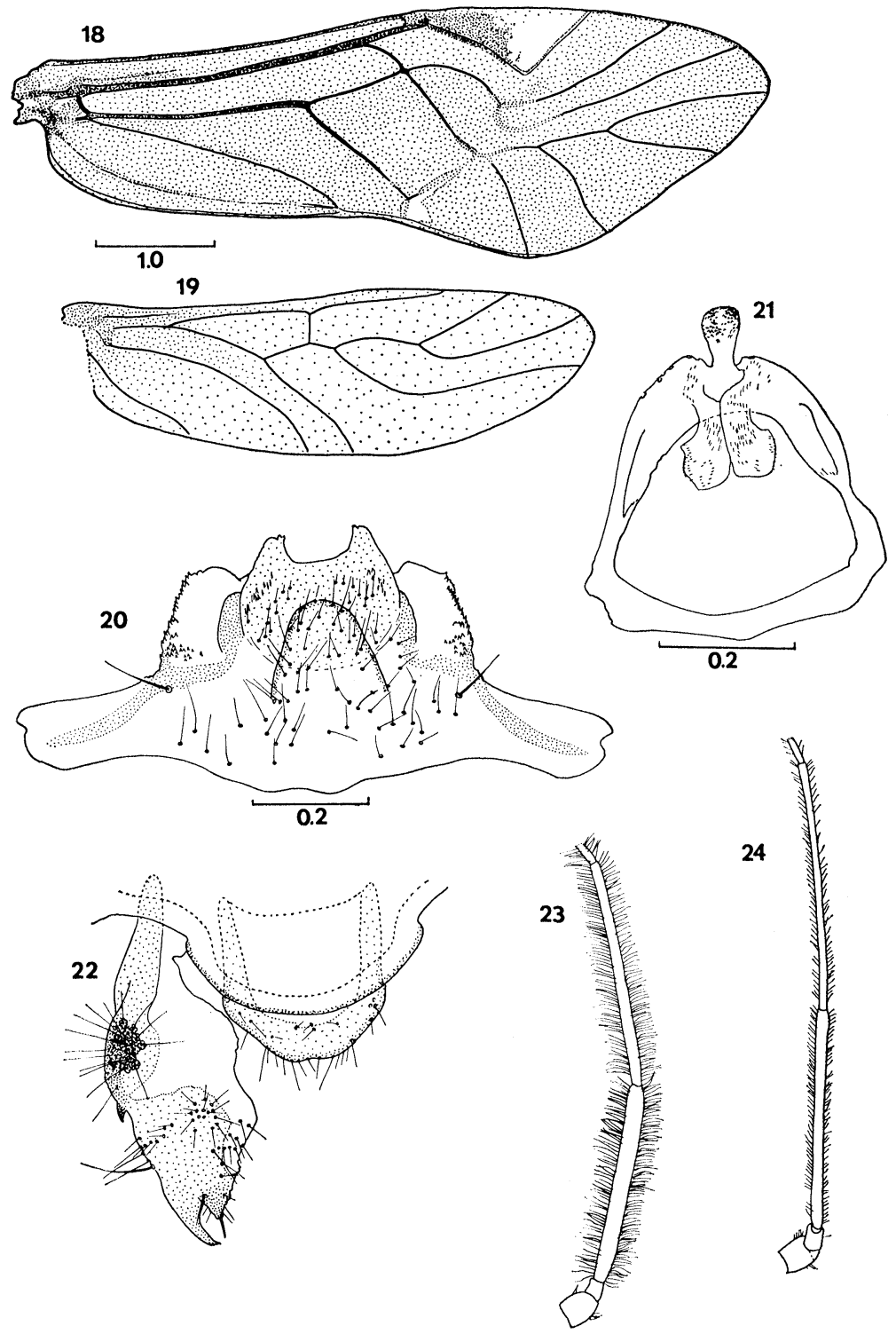


outlined in white. Veins of forewing white except following brown: short segment of Rs before its fork, short segments of $M$ before M-CuIa junction, $\mathrm{R}_{2}+3$, except its extreme base, $\mathrm{R}_{4}+5$ in its distal two-thirds, $M_{1}, M_{2}, M_{3}$, CuIa beyond junction with $M$. Hindwings (Fig. 2) uniformly pale fumose-brown. Coxae, trochanters and femora orange-brown; tibiae and tarsi duskier. Membranous portions of abdomen ringed with slender white stripes on a purplish-brown background (subcuticular pigment). Terminal abdominal segments medium to dark brown.

Female. - Measurements ('Table II).

Morphology. - Flagellomeres slender (Fig. 7). Subgenital plate (Fig. I I ) with pigmented area roughly $\mathrm{T}$-shaped as in E. infumatus but with narrow region of stem of $T$ shorter and setae distad of cross-piece shorter and not forming a distinct row, being interrupted in middle. Gonapophyses (Fig. I3) with first valvula acuminate distally, bearing a few minute spines on its edges; second valvula tapering distally and spinulose over distal third; third valvula with basal, more sclerotized region bearing setae (this region shown folded over rest in figure), remainder membranous, distal lobe straight. Ninth sternum and spermapore as in Fig. I6. Epiproct (Fig. 9) with clear region surrounded by approximately quadrate frame of heavier sclerotization, the frame and clear area bearing setae of various lengths.

Color. - Same as in male.

Material examined. - Brazil: Prov. Minas Gerais: Sao Joao del Rei, Coll. Sello, I वे(holotype); Santa Catarina: Nova Teutonia. November, I970, Coll. F. Plaumann, I 4 б , 23 ㅇ․ Uruguay: Depto. de Treinta y Tres: Rio Olimar Chico, $25 \mathrm{Km}$. WSW Treinta y Tres, I I April 1963, Coll. J. K. Bouseman, 8 o , 2 ‥

Eremopsocus nigripes, new species

Diagnosis. - Differing from E. infumatus in having only the first two flagellomeres incrassate and only in the male. Differing from $E$. crassicornis in having first two male flagellomeres decidedly more incrassate and having in both sexes posterior vertex of pterostigma angular, forming approximately a right angle, rather than rounded. Differing from the described fuscous-winged neotropical Cerastipsocus species in which external genitalia not known: from C. ocularis (Kolbe), C. moestus (Kolbe), C. pallidinervis (Kolbe), $C$. vetustus (Kolbe) in having pterostigma deep and with decidedly angular posterior vertex.

Male. - Measurements (Table II). 


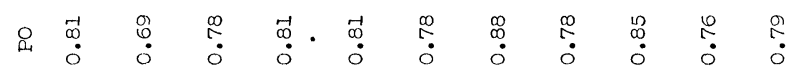

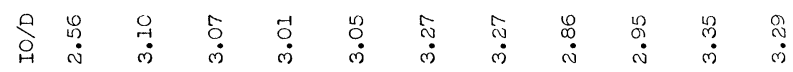

\%

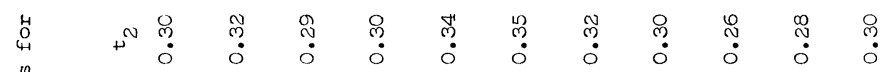

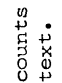

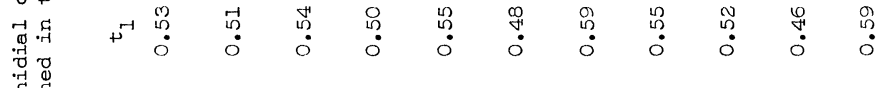

告

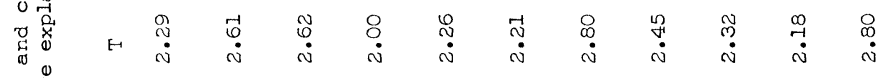

in $\begin{gathered}0 \\ 0\end{gathered}$

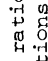

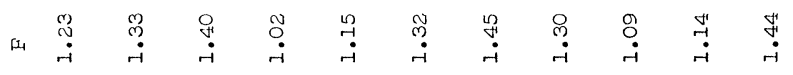

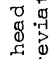

畐悬

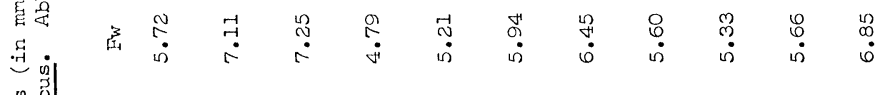

5
4
4
0
0
0
4
5
5
0
0
8
8

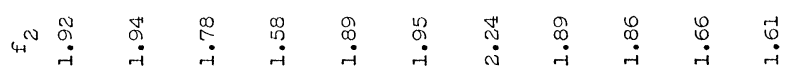

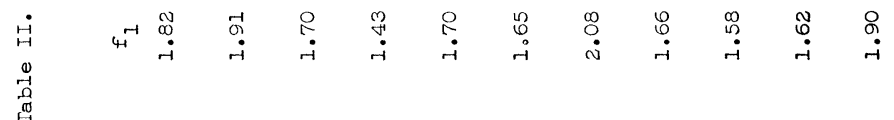

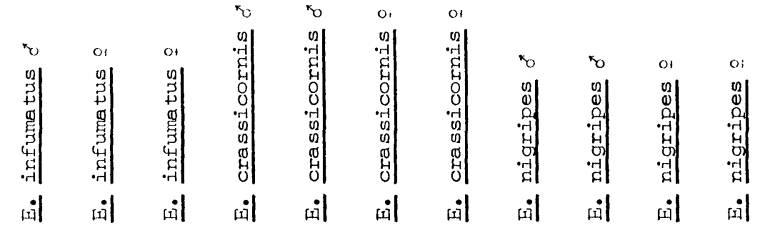


Morphology. - Basal flagellomere (Fig. 23) more incrassate than in E. crassicornis, second about the same, third to tip slender. All flagellomeres beset with upright hairs. Compound eyes small (see Table II). Hypandrium (Fig. 2O) with distal prongs somewhat longer than in E. crassicornis; these and sides of hypandrium, to extreme base beset with minute denticles. Discal lobe and regions to its sides and base bearing setae. Phallosome (Fig. 2I) symmetrical, with somewhat flattened base; the inset, spatulate distal process larger than in E. crassicornis and bearing minute denticles. Paraproct (Fig. 22) as in E. crassicornis. Epiproct and posterior clunial margin as in Fig. 22. The latter differing from that of E. crassicornis in having sides slightly indented.

Color (in alcohol). - Compound eyes and inner rims of ocelli black. Head yellow deepening to burnt orange on vertex with a spot of medium orange-brown in front of ocellar interval; clypeal striations faintly indicated by orange-brown mottling. Maxillary palpi pale brown on basal two segments, becoming darker distally on second; third segment dark brown, distal segment black. Antennal scape pale brown, rest of antenna black. Mesonotal lobes orange peripherally, deep orange-brown in a broad central band running length of mesonotum. Thoracic pleura violet. Forewing membrane (Fig. 18) uniformly fumose-brown except small region in base of areola postica extending distally along vein Cura; pterostigma and narrow stigmasaum white mottled in base with fumose brown. Veins of folewing fumose brown except following: R $\mathrm{R}_{\mathrm{I}}$ colorless from posterior apex of prerostigma to wing margin; Rs pale brown at and immediately before and in its junction with $\mathrm{CuIa}$, colorless immediately beyond junction; $\mathrm{Cu}$ a colorless before and immediately beyond junction with $\mathrm{M}$; Curb colorless. Hindwing (Fig. 19) uniformly pale fumose brown. Coxae, trochanters, and femora yellow; tibiae and tarsi black. Membranous portions of abdomen (note variation below) longitudinally striped with purple bands: a broad band along each side including spiracles, a narrower band along dorsal mid-line; an incomplete band ventrally from hypandrium, widest in 7 th segment, narrowing to its anterior end in third segment; abdomen creamy white between purple bands. Terminal abdominal segments largely dark brown, paler on poorly sclerotized portion.

Female. - Measurements ('Table II).

Morphology. - Flagellomeres slender (Fig. 24). Subgenital plate (Fig. I2) with norrow region of stem of T-shaped pigmented area shorter than in E. infumatus; setae distad of cross-piece of $\mathrm{T}$ 
shorter and forming a continuous subquadrate region. Lamp-globe shaped pigmented region distad of narrow portion of $\mathrm{T}$-stem not as broad as in $E$. crassicornis. Gonapophyses (Fig. I4) with second valvula not as long from broadest region to tip as in E. crassicornis; inner lobe of third valvula relatively longer. Epiproct (Fig. IO) with heavily sclerotized sides of distal clear area not decidedly pointing medially at their distal ends. Spermapore plate (Fig. I7) much as in E. crassicornis.

Color (in alcohol). - As in male except no spot of medium orange-brown before ocelli and three faint purple lines radiating from each compound eye medially.

Variation. - Some individuals lack the longitudinal purple bands of the abdomen but have, instead, transverse purple bands, one per segment, each band dividing into two at the spiracle on each side and continuing ventrally as two narrow bands which dissipate before reaching the ventral mid-line. These individuals have the dark pigmentation of the mesonotum more diffuse and, in males, the dark pigmentation of the pterostigma and stigmasaum more dispersed. I can detect no morphological difference between these and the form described above. The two forms were apparently collected together.

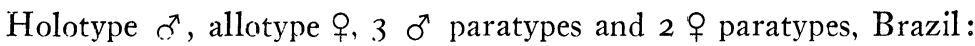
Santa Catarina: Nova Teutonia, November, 1970, Coll. F. Plaumann. Types will be deposited in the United States National Museum, Washington, D. C.

Other material examined. - (all from Nova Teutonia, Santa Catarina, Brazil, Fritz Plaumann collector). Same data as holotype,

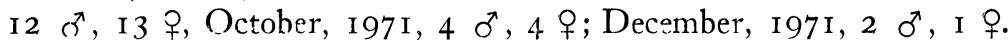

Key to the Species of Eremopsocus

Ia. First four flagellomeres incrassate in both sexes. Female subgenital plate with a single row of long setae along cross-piece of $\mathrm{T}$-shaped mark E. infumatus McLachlan

Ib. At most first two flagellomeres incrassate, and these only $i_{1}$ : male. Female subgenital plate with scattered setae bordering cross-piece of $\mathrm{T}$-shaped mark, these not forming a single row

2a. Pterostigma with angular posterior apex. Veins in basal half of forewing, especially $\mathrm{M}+\mathrm{Cu}$ i brown, not contrasting sharply with wing membrane. First male flagellomere decidedly incrassate (Fig. 4) E. nigripes n. sp. 
2b. Pterostigma with rounded posterior apex. Veins in basal half of forewing, especially $\mathrm{M}+\mathrm{Cu}$ white, contrasting strongly in well colored individuals with fumose wing membrane. First male flagellomere only slightly incrassate

E. crassicornis (Kolbe).

Acknowledgments. - Material examined in this paper was in part borrowed from the following institutions: American Museum of Natural History, New York City; Los Angeles County Museum, Los Angeles, California; Museum für Naturkunde, Humboldt Universität, Berlin, D. D. R.; Snow Entomological Museum, Lawrence, Kansas; United States National Museum, Washington, D. C. I wish to thank the officers of these institutions for arranging the loans. I wish to thank the following individuals for gifts of specimens: Mr. John K. Bouseman, (Illinois Natural History Survey, Urbana, Illinois), Dr. J. M. Campbell (Department of Agriculture of Canada, Ottawa, Ontario, Canada), Dr. Henry F. Howden (Carleton University, Ottawa, Ontario, Canada).

\section{Literature Cited}

Chapman, P. J.

1930. Corrodentia of the United States of America: I. Suborder Isotecnomera. Journ. N. Y. Ent. Soc. 38: 219-290, 318-402.

ENDERLEIN, G.

1911. Die fossilen Copeognathen und ihre Phylogenie. Palaeontographica $58: 279-360$.

Kolbe, H. J.

1883. Neue Psociden des Königl. Zoologischen Museums zu Berlin. Stett. Ent. Zeit. 44: 65-87.

McLachlan, $R$.

1866. New genera and species of Psocidae. Trans. R. Ent. Soc. Lond. $5: 345-352$.

MOCKFORD, E. L.

1974. Records and descriptions of Cuban Psocoptera. Ent. Americana 48 : 103-215.

New, T. R.

1972. A collection of Psocidae (Psocoptera) from central Brazil. Arq. Zool. 22: 193-237.

Pearman, J. V.

1933. A psocid allied to Eremopsocus infumatus McLachlan (Psocop-

ROESLER, R. tera). Stylops 2: 159-161.

1944. Die Gattungen der Copeognathen. Stett. Ent. Zeit. 105: 117-166. SMITHERS, C. N.

1967. A catalogue of the Psocoptera of the World. Austr. Zool. 16: 1-145. 

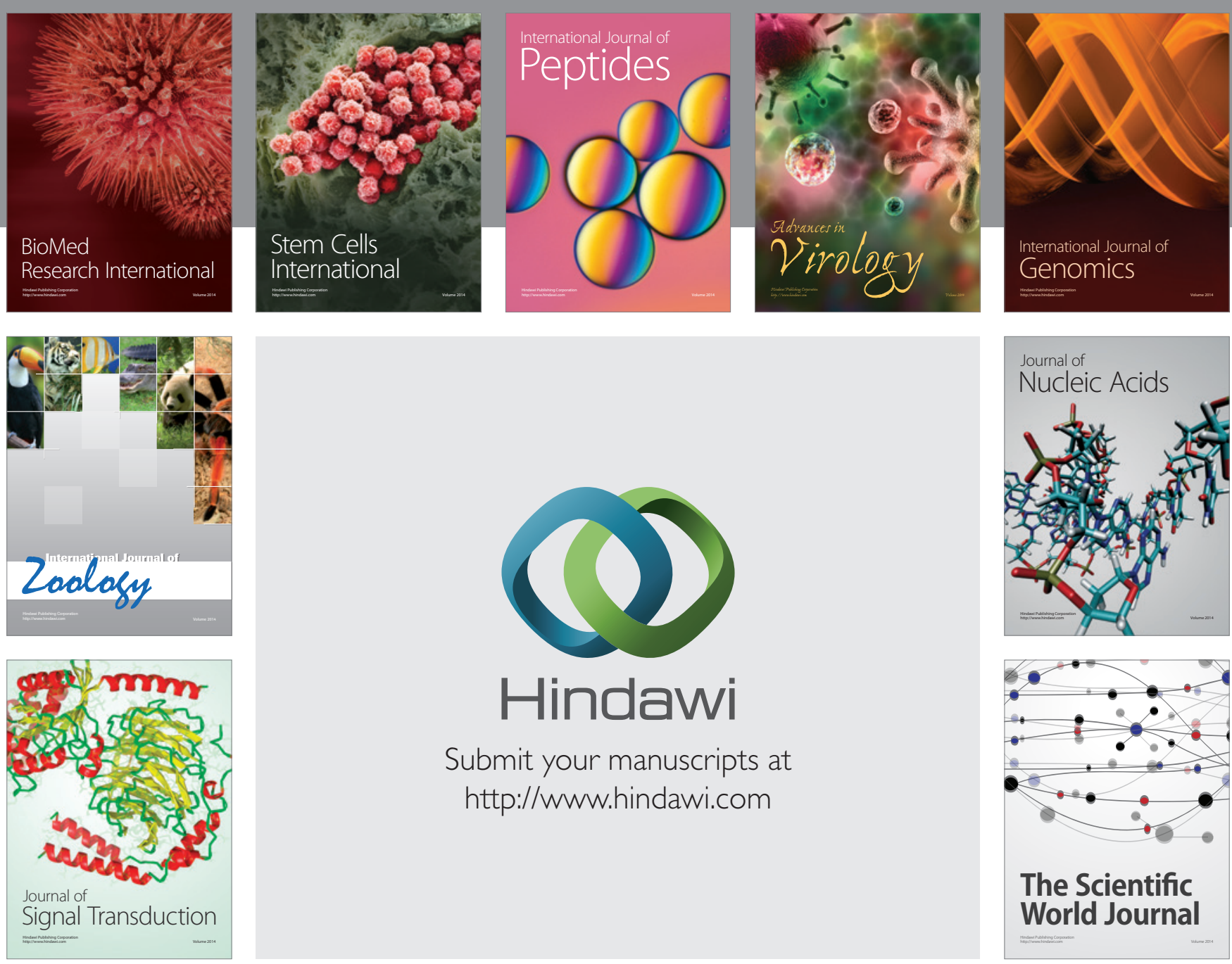

Submit your manuscripts at

http://www.hindawi.com
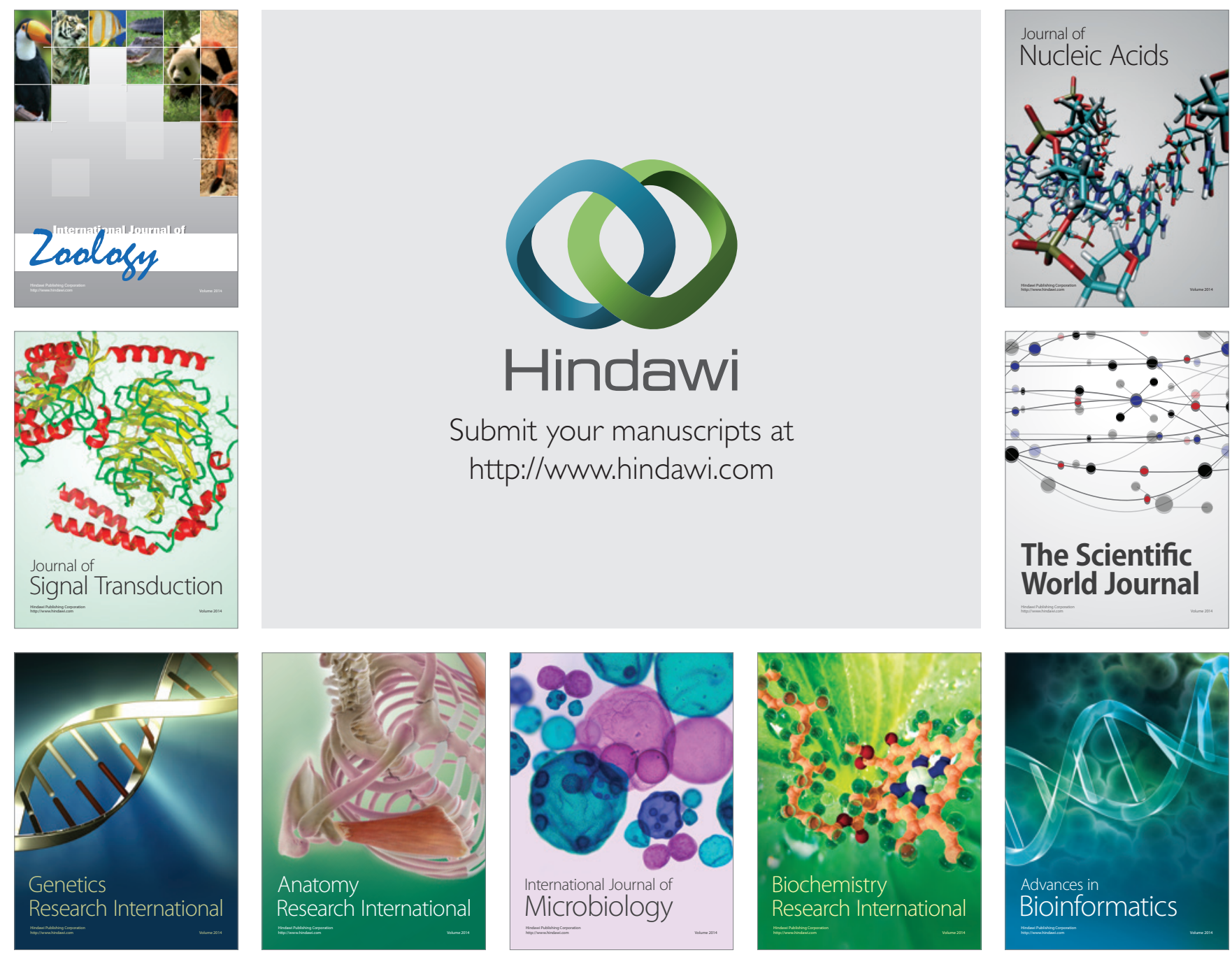

The Scientific World Journal
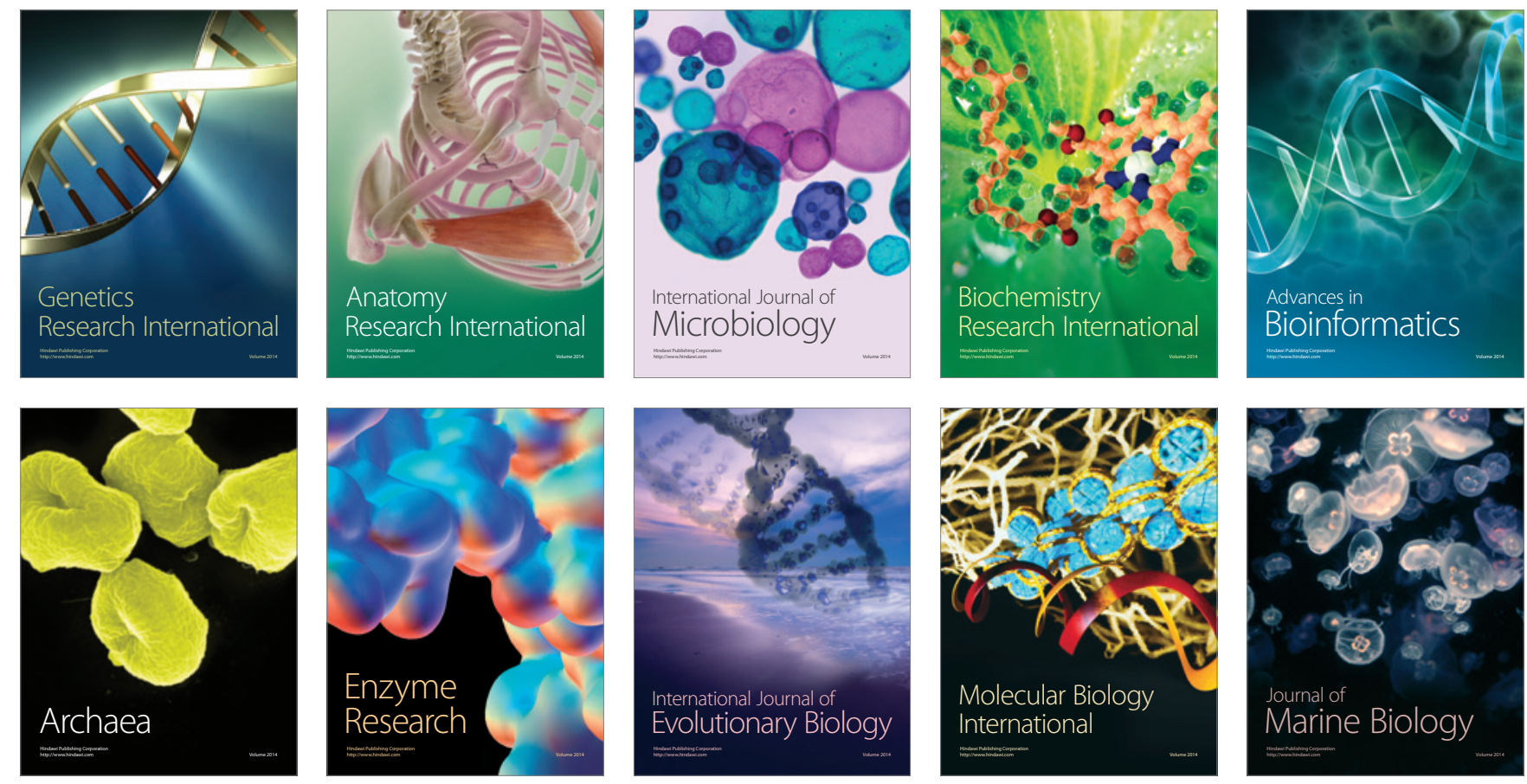